\title{
PEMANFAATAN FONETIK ARTIKULATORIS UNTUK PENINGKATAN KEMAMPUAN PELAFALAN BAHASA SASAK ANAK DOWN SYNDROME RINGAN DI LOMBOK TIMUR
}

\author{
Bayu Islam Assasaki \\ email: bayuassasaki@gmail.com \\ Lombok, NTB \\ I Wayan Pastika \\ email: wayanpastika@unud.ac.id \\ Program Magister Linguistik, Universitas Udayana \\ I Nyoman Suparwa \\ email: suparwa_nym@yahoo.co.id \\ Program Magister Linguistik, Universitas Udayana
}

\begin{abstract}
Abstrak-Penelitian ini bertujuan untuk meningkatkan kemampuan pelafalan anak down syndrome ringan dalam berbicara bahasa Sasak di Kabupaten Lombok Timur melalui pemanfaatan fonetik artikulatoris dengan metode pengajaran intensif.

Penelitian ini menerapkan desain penelitian kelas (PTK) yang dilakukan sebanyak dua siklus dengan menerapkan empat tahap kegiatan yaitu perencanaan, tindakan, observasi dan refleksi. Metode analisis data menggunakan metode analisis deskriptif kualitatif dan didukung dengan deskriptif kuantitatif. Hasil analisis data disajikan dalam bentuk tabel dan diagram.

Dalam penelitian ini peningkatan kemampuan pelafalan anak down syndrome ringan dibuktikan dengan hasil data kualitatif seperti hasil yang didapatkan dari tes yang dilakukan, lembar observasi dan dokumentasi. Peningkatan kemampuan pelafalan pada siswa juga dibuktikan dengan berkurangnya kesalahan pelafalan pada siswa baik dari pelafalan bunyi vokal, bunyi konsonan dan pelafalan kata atau frasa. Peningkatan kemampuan pelafalan siswa juga ditandai dengan meningkatnya nilai rata-rata yang diperoleh sejak tes awal yaitu sebesar 54,40 $\%$, pada siklus I mengalami peningkatan menjadi $68,62 \%$, dan pada siklus II mengalami peningkatan menjadi $76,75 \%$.
\end{abstract}

Kata Kunci-kemampuan pelafalan, down syndrome, fonetik artikulatoris.

\begin{abstract}
This research was aimed to improve Sasak pronunciation skill for mild down syndrome children in East Lombok through the use of articulatory phonetic with intensive teaching method.

This study applied a classroom action research design which applies four steps namely planning, action, observation, and reflection. This research was conducted into one cycle by applying those four steps action research design. Analyzing data was done by describing the result of qualitative and quantitative data. The result of data analysis is presented into table and chart as well as is described into narrative sentences.
\end{abstract}


LINGUISTIKA, SEPTEMBER 2018

p-ISSN: 0854-9613

Vol. 49. No. 25

In this research the improvement of students' pronunciation skill in speaking Sasak language were proven by the result of qualitative data, such as the result of test, observation, taking note and also documentation. The use of articulatory phonetics has successfully improved the students' pronunciation skill especially in pronouncing vowel sound, consonant sound and pronouncing word or phrase. The improvement of students' speaking skill were also proven by the improvement of mean score between pretest, cycle I posttest and cycle II posttest. The mean score showed that the improvement from $54,40 \%$ on pretest to $68,62 \%$ and finally became $76,75 \%$ on cycle II

Keywords-pronunciation skill, down syndrome, articulatory phonetic. 
Keterampilan berkomunikasi baik dari segi lisan maupun tulisan merupakan suatu keterampilan bahasa yang perlu bahkan harus dikuasai dengan baik. Pentingnya keterampilan berbahasa dan berbicara ini tidak terkecuali bagi para penderita down syndrome. Down syndrome adalah suatu kondisi keterbelakangan perkembangan fisik dan mental anak yang diakibatkan adanya abnormalitas perkembangan kromosom. Kelainan ini yang menyebabkan penderita mengalami gangguan fisik dan mental yang secara tidak langsung memengaruhi kemampuan mereka, yaitu salah satunya terganggunya kemampuan dan keterampilan berbicara (Sulastowo, 2008).

Banyak masyarakat yang masih belum mengetahui bahwa anak down syndrome dapat ditingkatkan keterampilan mereka dalam berkomunikasi khususnya pelafalan berbicara dengan melatih kemampuan bahasa mereka secara intensif. Masyarakat memiliki peran sangat penting dalam upaya meningkatkan kemampuan pelafalan anak down syndrome karena masyarakat adalah kelompok individu yang menggunakan bahasa dalam kehidupannya sehari-hari, sehingga merupakan kelompok yang paling penting di dalam berkomunikasi sampai penciptaan ortografi (Suparwa, 2008).

Kurangnya pengetahuan masyarakat tentang anak down syndrome ini juga terjadi di Pulau Lombok Nusa Tenggara Barat, khususnya di Kabupaten Lombok Timur. Orang tua tidak mencoba untuk melatih anak down syndrome untuk meningkatkan kemampuan pelafalan berbicara mereka untuk berkomunikasi seharihari dalam menggunakan bahasa Sasak. Hal itu diperberat dengan kurangnya ketersediaan fasilitas pendidikan untuk anak berkebutuhan khusus.

Kabupaten Lombok Timur terletak cukup jauh dari ibu kota provinsi, sehingga hanya memiliki satu Sekolah Luar Biasa (SLB) dan itu hanya terdapat di kota Selong. Sementara, Kabupaten Lombok Timur merupakan kabupaten yang terluas di Nusa Tenggara Barat. Oleh sebab itu, bagi desa-desa yang letaknya cukup jauh tidak mendapat perhatian yang khusus dalam menangani masalah anak-anak yang berkebutuhan khusus tersebut.

Kabupaten Lombok Timur hanya memiliki satu yayasan yaitu Yayasan Pondok Harmoni sebagai tempat untuk memberikan pendidikan bagi anak-anak berkebutuhan khusus yang terletak di desa Sakra. Hal ini tentunya mengakibatkan banyak anak yang berkebutuhan khusus terutama anak down syndrome ringan tidak mendapatkan penanganan untuk mengatasi masalah kemampuan pelafalan mereka. Santrock (2011) menyatakan bahwa penanganan terhadap anak down syndrome hendaknya dilakukan dengan segera, baik dari segi perhatian, pendampingan, menyediakan waktu yang khusus dan masih banyak lagi. Di negara maju banyak anak dengan down syndrome yang tumbuh menjadi pribadi yang mandiri, terampil dan dapat berkomunikasi dengan baik.

Dengan metode yang tepat masalah seperti ini bisa diatasi. Salah satunya adalah dengan pemanfaatan fonetik artikulatoris yang diajarkan secara intensif diharapkan mampu meningkatkan kemampuan pelafalan anak down syndrome ringan di Yayasan pondok Harmoni Desa Sakra Kabupaten Lombok Timur.

Berdasarkan fenomena yang telah dijelaskan, penelitian mengenai pemanfaatan fonetik untuk meningkatkan kemampuan pelafalan anak down syndrome ringan di Kabupaten Lombok Timur dilaksanakan dengan rumusan masalah sebagai berikut.

1) Bunyi apa sajakah yang sulit dilafalkan anak penderita down syndrome ringan dalam berbicara dalam bahasa Sasak sebelum pemanfaatan fonetik artikulatoris melalui metode intensif?

2) Bagaimanakah kemampuan pelafalan anak down syndrome ringan dalam berbicara bahasa Sasak setelah pemanfaatan fonetik artikulatoris melalui metode intensif?

Secara umum, penelitian ini bertujuan untuk meningkatkan kempapuan pelafalan bahasa Sasak pada anak penderita down syndrome 
ringan. Selanjutnya penelitian ini secara khusus bertujuan untuk mengetahui kemampuan pelafalan anak down syndrome ringan sebelum dan sesudah proses pengajaran melalui pemanfaatan fonetik artikulatoris dilakukan.

\section{METODE PENELITIAN}

Penelitian ini merupakan penilitian dengan desain Penelitian Tindakan Kelas (PTK) dengan pendekatan kualitatif dan pendekatan kuantitatif sebagai pendukung. Penelitian ini menggunakan desain PTK model Mc Taggart (2010) sebanyak dua siklus dengan masingmasing siklus memiliki empat tahapan yaitu perencanaan, tindakan, pengamatan dan refleksi.

Pengumpulan data dalam penelitian ini dilakukan melalui tes, pengamatan atau observasi dan perekaman. Tes dibagi menjadi dua, yaitu tes awal dan tes akhir. Tes awal diberikan untuk mengetahui kemempuan berbicara khususnya pelafalan anak down syndrome ringan sebelum pemanfaatan fonetik artikulatoris melalui metode intensif dilakukan, sedangkan tes akhir diberikan setelah pemanfaatan fonetik artikulatoris melalui metode intensif dilakukan.

Metode yang digunakan dalam menganalisis data yaitu metode deskriptif kualitatif dan didukung dengan metode kuantitatif. Pada data kualitatif, analisis dilakukan secara deskriptif kualitatif sedangkan data angka yang dapat dianalisis dengan metode kuantitatif. Data diperoleh dari data hasil tes awal kemampuan pelafalan responden sebelum pemanfaatan fonetik artikulatoris dilakukan dan tes akhir yakni nilai kemampuan pelafalan responden setelah pemanfaatan fonetik artikulatoris dilakukan .Hasil dari kedua data tersebut kemudian dianalisis secara deskriptif lalu dikoreksi dengan memberikan nilai. Aspek penilaian didasarkan pada kemampuan responden dalam melafalkan bahasa ibu dari tes awal sampai tes akhir. Hasil dari setiap tes akan dibandingkan antara satu dengan yang lain.

\section{HASIL PENELITIAN DAN PEMBAHASAN}

Hasil penelitian yang berupa data selama melaksanakan penelitian dijabarkan serta dianalisis dengan menggunakan beberapa teori yang telah dijadikan sebagai acuan penelitian yaitu teori fonetik artikulatoris dan keterampilan berbicara. Selama penelitian berlangsung, diterapkan pemanfaatan fonetik artikulatoris dalam proses belajar mengajar untuk mendukung peningkatan pelafalan berbicara bahasa Sasak pada anak down syndrome ringan di Yayasan Pondok Harmoni Kecamatan Sakra Kabupaten Lombok Timur.

\section{Teori Fonetik Artikulatoris}

Fonetik artikulatoris atau yang dikenal juga dengan sebutan fonetik fisiologis adalah bagian dari bidang ilmu fonetik yang mempelajari bagaimana mekanisme alat-alat bicara manusia bekerja dan menghasilkan bunyi bahasa serta bagaimana bunyi-bunyi itu di klasifisakan, atau bunyi bahasa dengan menggerakkan atau memanfaatkan organ-organ tuturnya, misalnya lidah, bibir dan gigi bawah yang digerakkan oleh rahang bawah. (Singh dan Singh, 1976:2).

Selain mempelajari proses produksinya, fonetik artikulatoris juga mempelajari asimilasi bunyi, yaitu perubahan bunyi bahasa akibat adanya pertemuan bunyi bahasa yang satu dengan bunyi bahasa yang lain di dalam satu rentetan bunyi/tuturan. Misalnya, di dalam bahasa Arab, fon apikodental nasal [n] di akhir suku kata yang bertemu dengan bilabial plosif [b] di awal suku kata selanjutnya mengakibatkan [n] berubah menjadi bilabial nasal [m] (Muslich, 2012:9).

\section{Teori Keterampilan Berbicara}

Tarigan (2008:17) mendefinisikan keterampilan berbicara sebagai kemampuan mengungkapkan bunyi-bunyi artikulasi atau katakata untuk mengekspresikan, menyatakan, serta menyampaikan pikiran, gagasan, dan perasaan. Hornby (2005) mendefinisikan berbicara 
(speaking), sebagai"to talk to somebody about something,to have a conversation with somebody". Jadi, berbicara adalah sebuah kegiatan yang dilakukan seseorang kepada orang lain tentang suatu hal atau kegiatan percakapan yang dilakukan seseorang kepada orang lain.

Kemampuan berbicara adalah kemampuan mengucapkan bunyi-bunyi artikulasi atau mengucapkan kata-kata untuk mengekspresikan, menyatakan, menyampaikan pikiran, gagasan dan perasaan (Maidar dan Mukti, 2000). Berbicara merupakan kegiatan bahasa yang paling purba, jauh mendahului peradaban manusia dalam aspek yang lain. Oleh karena itu, berbicara sering dianggap sebagai hakikat inti dari berkomunikasi.

\section{HASIL TES PELAFALAN AWAL}

Pada penelitian ini terlebih dahulu dilakukan pretest. Pretest atau tes awal merupakan kegiatan menguji tingkat kemampuan siswa sebelum memulai pelajaran yang bertujuan untuk mengukur sejauh mana kemampuan siswa sebelum proses belajar dilakukan (Ganditama, 2014). Dalam penelitian ini pretest atau tes pelafalan awal dilakukan untuk menetahui bunyi apasajakah yang sulit dilafalkan oleh peserta didik baik bunyi vokal, konsonan, kata maupun frasa, sehingga dapat diketahui bunyi apasaja yang harus difokuskan dalam proses pembelajaran. Hasil pretest atau tes awal pelafalan menunjukkan bahwa tingkat kemampuan pelafalan siswa dalam berbicara bahasa Sasak dapat dilihat pada tabel dibawah ini.

Persentase Nilai Tes Awal (Pretest) Pelafalan Siswa

\begin{tabular}{llll}
\hline NO & SISWA & $\begin{array}{l}\text { NILAI } \\
\text { TOTAL }\end{array}$ & KATEGORI \\
\hline 1 & Siswa 1 & $39 \%$ & Sangat Kurang \\
\hline 2 & Siswa 2 & $50 \%$ & Kurang \\
\hline 3 & Siswa 3 & $50 \%$ & Kurang \\
\hline 4 & Siswa 4 & $42 \%$ & Kurang \\
\hline 5 & Siswa 5 & $61 \%$ & Cukup \\
\hline 6 & Siswa 6 & $64 \%$ & Cukup \\
\hline 7 & Siswa 7 & $58 \%$ & Kurang \\
\hline
\end{tabular}

\begin{tabular}{llcl}
\hline 8 & Siswa 8 & $69 \%$ & Cukup \\
\hline & Nilai & Rata-Rata & Kurang \\
& Siswa $=\mathbf{5 4 , 4} \%$ & \\
\hline
\end{tabular}

Tabel di atas menunjukkan bahwa nilai rata-rata yang diperoleh siswa adalah 54,4\%. Berdasarkan tabel Kriteria Acuan Penilaian Keterampilan Berbicara oleh Simon (2005:17), nilai rata-rata yang diperoleh siswa pada tes awal ini termasuk dalam kategori kurang. Terdapat 4 orang siswa memiliki tingkat kemampuan yang tergolong masih kurang dalam melafalkan bahasa Sasak. Terdapat juga salah seorang siswa yang mendapatkan nilai yang sangat kurang, meskipun ada 3 orang siswa yang memiliki kemampuan yang cukup dalam melafalkan bahasa Sasak. Hal ini juga berarti bahwa tingkat kemampuan pelafalan siswa dalam melafalkan bahasa Sasak baik dari segi bunyi vokal, konsonan, kata maupun frasa masih tergolong kurang atau rendah. Adapun kesalahan pelafalan yang dilakukan oleh anak down syndrome ringan di Pondok Harmoni Lombok Timur meliputi kesalahan dalam melafalkan bunyi vokal, kesalahan dalam melafalkan bunyi konsonan, kesalahan dalam melafalkan kata, dan kesalahan dalam melafalkan frasa.

\section{1) Kesalahan Pada Bunyi Vokal}

Karakteristik yang khas pada bagian fisik anak down syndrome khususnya pada bagian alat ucap seperti besarnya ukuran lidah, bibir tebal, rongga hidung sempit dan posisi rahang yang tidak sempurna menyebabkan gangguan artikulatoris menjadi deficit yang sangat menonjol (Santrock, 2011).

Bunyi vokal disebut juga bunyi vokoid, yaitu bunyi yang dihasilkan tanpa melibattkan penyempitan atau penutupan pada daerah artikulasi (Muslich, 2008). Hasil tes awal pada bunyi vokal dalam penelitian ini menunjukkan bahwa para siswa sebagian besar telah mampu melafalkan bunyi vokal, meskipun ada beberapa siswa yang masih belum bisa melafalkan dengan benar. 
Berdasarkan tabel hasil tes awal dalam pelafalan bunyi vokal pada siswa menunjukkan bahwa nilai rata-rata yang diperoleh termasuk dalam kategori baik. Hasil ini menunjukkan bahwa anak down syndrome lebih mudah melafalkan bunyi vokal dibandingkan dengan bunyi konsonan. Hal ini disebabkan oleh bunyi vokal merupakan bunyi yang timbul tampa ada hambatan pada alat bicara. Sekalipun ada hambatan, itu hanya terjadi pada pita suara (Marsono, 2006).

Hasil pada tes awal menunjukkan bahwa sebanyak $12 \%$ atau 1 dari 8 orang siswa masingmasing masih salah melafalkan bunyi vokal $a$ yang seharusnya dilafalkan [ a ] tetapi dilafalkan dengan $[\varepsilon$ ] seperti dalam kata inak yang lafalnya [ ina? ] dilafalkan dengan bunyi [ in $\varepsilon$ ] dan bunyi vokal $i$ yang lafalnya [ i ] dilafalkan dengan [ e ], seperti dalam kata nani yang lafalnya [nani] dilafalkan dengan [ ñañe ]. Sebanyak $38 \%$ atau 3 dari 8 orang masih salah dalam melafalkan bunyi vokal $e$ yang seharusnya dilafalkan [ $ә$ ] tetapi dilafalkan dengan [ e ] seperti dalam kata apel yang lafalnya [ apəl ] dilafalkan dengan [ apey ] dan kata kake yang lafalnya [ kakə ] dilafalkan dengan [ kake ]. Sebanyak $25 \%$ atau 2 dari 8 orang masih salah dalam melafalkan bunyi vokal $e$ yang seharusnya dilafalkan [ $\varepsilon$ ] tetapi dilafalkan dengan [ e ] seperti pada kata teh yang lafalnya [tch ] dilafalkan dengan [ teh ]. Untuk bunyi vokal [ $\mathrm{O}$ ] dan [ o ] masing-masing sebanyak $25 \%$ atau 2 dari 8 siswa masih salah dalam melafalkan bunyi vokal tersebut. Siswa melafalkan bunyi vokal $o$ yang seharusnya dilafalkan [O ] tetapi dilafalkan dengan bunyi [ $\mathrm{O}$ ] seperti dalam kata lalo yang lafalnya [ lalo ] dilafalkan dengan [ yayO ] dan melafalkan bunyi vokal $o$ yang seharusnya dilafalkan [o] tetapi dilafalkan dengan bunyi [ u ] seperti kata pano yang lafalnya [ pano ] dilafalkan [ panu ].

\section{2) Tes Awal Bunyi Konsonan}

Ketidak sempurnaan alat ucap pada anak down syndrome mengakibatkan penyimpangan fonologi sehingga bunyi-bunyi yang dilafalkan anak menjadi tidak jelas dan sulit untuk dimengerti bagi yang mendengarkan. Bunyi konsonan merupakan bunyi yang terjadinya dibentuk dengan menghambat arus udara pada setiap alat bicara dan disertai dengan bergetarnya pita suara (Baihaqi, 2011). Ketidaksempurnaan lidah dan bibir menjadi penyebab utama hal ini terjadi. Dalam berbicara lidah memiliki peranan yang sangat penting saat proses berbicara. Setiap bagian lidah memiliki fungsi tersendiri dalam proses pembentukan bunyi. Baihaqi (2011) juga menyatakan bahwa macroglossia pada anak down syndrome telah memengaruhi fungsi kerja berbagai bagian dari lidah.

Hasil tes awal menunjukkan bahwa nilai rata-rata yang diperoleh siswa termasuk dalam kategori kurang. Bagi anak down syndrome, ketidak sempurnaan alat ucap mengakibatkan bunyi konsonan lebih sulit untuk dilafalkan jika dibandingkan dengan melafalkan bunyi vokal.

Bentuk bibir yang mengecil dan bentuk lidah yang menonjol pada anak down syndrome menimbulkan kesulitan dalam melafalkan bunyibunyi konsonan seperti konsonan bilabial $b, p$ atau $m$ yang lafalnya [ b ] , [ $\mathrm{p}$ ] dan [ $\mathrm{m}$ ] seperti pada kata bait yang lafalnya [ baIt ] dilafalkan dengan [ aIt ], kata pade yang lafalnya [padə] dilafalkan dengan [ atə ] dan kata maik yang lafalnya [mai?] dilafalkan dengan [ai]. Hal ini disebabkan oleh anak down syndrome sulit untuk merapatkan bibir atas dan bibir bawah juga menggetarkan lidah. Selain itu hal ini juga berakibat sulitnya anak down syndrome melafalkan bunyi homorgan seperti bunyi yang lafalnya [ t ] dan [ d ] atau [ p ] dan [ b ], sehingga bunyi-bunyi tersebut sering dilafalkan berubah atau terjadi disposisi (Baihaqi, 2011). Contohnya kata tedem yang lafalnya [ tedəm ] dilafalkan [ detcom ] atau kata pait yang lafalnya [ pait] dilafalkan [ bait ].

Dari hasil tes awal juga didapatkan bahwa siswa cenderung melafalkan konsonan $k$ yang seharusnya dilafalkan [ $\mathrm{k}$ ] tetapi dilafalkan dengan bunyi [ $\mathrm{t}$ ] atau bunyi g yang seharusnya dilafalkan $[\mathrm{g}$ ] tetapi dilafalkan dengan bunyi $[\mathrm{h}$ 
] atau bunyi [ c ] ataupun bunyi [ t ]. Contohnya pada kata kakak yang lafalnya [ kaka? ] dilafalkan dengan [ tca tca ] dan kata gawe yang lafalnya [ gawe ] dilafalkan dengan bunyi [ hawe ]. Anak down syndrome ringan mempunyai kesulitan dalam melafalkan bunyi-bunyi dorso velar terutama bunyi $[\mathrm{k}]$ dan [ $\mathrm{g}$ ] dalam posisi awal, tengah, dan akhir kata. Kedudukan ini melibatkan artikulator pangkal lidah dengan langit-langit lunak. Sehingga dalam melafalkan kata yang berawalan bunyi ini anak down syndrome cenderung mengganti fonem tersebut seperti kata gule yang lafalnya [ gulə ] dilafalkan dengan [ tulə] atau kata kake yang lafalnya [ kakə ] dilafalkan dengan bunyi [tcatə].

Anak down syndrome mempunyai kesulitan dalam melafalkan bunyi nasal $[\mathrm{n}]$ dan $[\eta]$ dalam posisi huruf mati (baik di akhir kata atau di akhir suku kata) yang dilafalkan dengan bunyi nasal yang dalam hal ini cenderung melafalkan bunyi [ $\tilde{n}$ ] atau menjadi hilang. Sehingga kata yang berawalan bunyi ini cenderung dilafalkan dengan mengganti fonem tersebut seperti kata nginem yang lafalnya [ cenderung dilafalkan [ ñiñəm ]

Hampir semua siswa $(87,50 \%$ atau 7 orang siswa) masih salah dalam melafalkan konsosnan $r$ yang seharusnya dilafalkan [ $r$ ]tetapi dilafalkan dengan [y] dan [1] seperti pada kata jeruk yang lafalnya [ jorUk ] dilafalkan dengan bunyi [cəyUk]. Bunyi [ $r$ ] merupakan bunyi getar yang dihasilkan dengan cara arus udara ditutup dan dibuka berulang ulang secara cepat. Pada konsonan $l$ juga terjadi kesalahan pelafalan, yaitu sebanyak 4 orang siswa melafalkan konsonan $l$ yang seharusnya dilafalkan [1] tetapi dilafalkan dengan bunyi [ y ] seperti pada kata lalo yang lafalnya [ lalo ] dilafalkan dengan bunyi [ yayo ].

\section{3) Tes Awal Pelafalan Kata atau Frasa}

Bentuk kesalahan pelafalan dari segi penghilangan fonem pada anak down syndrome ringan misalnya terjadi saat melafalkan kata kakak yang lafalnya [kaka?] dilafalkan dengan [ tata? ] atau pada kata bait yang lafalnya [ baIt ] dilafalkan dengan [ aIt ]. Selain itu penghilangan fonem juga terjadi ketika melafalkan frasa seperti gule beak yang lafalnya [ gulə beya? ] dilafalkan dengan [ uyə cya ].

Bentuk kesalahan pelafalan dari segi pengubahan fonem pada anak down syndrome ringan misalnya terjadi saat melafalkan kata pade yang lafalnya [ padə] dilafalkan dengan [ pate ] atau pada kata sambel yang lafalnya [ sambəl ] dilafalkan dengan [ cambey ]. Selain itu pengubahan fonem juga terjadi ketika melafalkan frasa seperti amak kake yang lafalnya [ ama? kakə] dilafalkan dengan [ ama tata ].

Bentuk kesalahan pelafalan dari segi penghilangan atau pengubahan suku kata pada anak down syndrome ringan misalnya terjadi saat melafalkan kata sebie yang lafalnya [ səbiyə ] dilafalkan dengan [ biyə ] sehingga suku kata [ sə ] yang menjadi awal kata dengan struktur kontoid vokoid $(\mathrm{KV})$ tidak dilafalkan.

\section{PELAKSANAAN TINDAKAN KELAS}

Dalam pelaksanaan setiap siklus dalam penelitian ini terlebih dahulu dilakukan perencanaan, kemudian pelaksanaan, selanjutnya dilakukan observasi dan refleksi.

Sebelum dilakukan proses pengajaran melalui pemanfaatan fonetik artikulatoris secara intensif, terlebih dahulu dibuat persiapan seperti menyiapkan materi, menyiapkan rencana Pelaksanaan Pembelajaran (RPP), dan menyiapkan instrument seperti buku catatan, lembar observasi dan kamera video (handycam) untuk melakukan perekaman. Materi yang digunakan dalam pelaksanaan setiap siklus adalah materi yang disusun sendiri yang terdiri dari materi pengajaran untuk bunyi vokal, bunyi konsonan, pelafalan kata dan pelafalan frasa.. Dalam penelitian ini rencana pelaksanaan pembelajaran (RPP) bertujuan untuk mempermudah, memperlancar dan meningkatkan hasil proses belajar mengajar di dalam kelas. Terdapat tiga instrument yang digunakan dalam penelitian ini yaitu buku catatan, lembar observasi dan alat perekam yang berupa handycam.

Pelaksanaan dilakukan agar siswa down syndrome ringan yang ada di Pondok Harmoni 
Lombok Timur mampu meningkatkan kemampuan pelafalan berbicara dalam bahasa Sasak sehingga bunyi yang dilafalkan oleh siswa menjadi lebih jelas dan dapat dimengerti. Sebelum proses pengajaran dimulai, para siswa terlebih dahulu diarahkan kedalam ruangan khusus dan lebih nyaman agar siswa menjadi lebih fokus dalam belajar dan bunyi yang diajarkan dapat didengar lebih jelas, cara melafalkan bunyi dapat dilihat dengan lebih jelas sehingga hasilnya akan lebih maksimal. Para siswa diajarkan cara melafalkan bunyi dalam bahasa Sasak mulai dari bentuk atau posisi bibir dan lidah sesuai dengan ilmu fonetik artikulatoris yang kemudian diikuti oleh siswa satu persatu. Hal ini dilakukan secara intensif sampai siswa mulai mampu melafalkan bunyi dengan benar.

Kegiatan selanjutnya yaitu dilakukannya observasi untuk mengetahui hasil pelaksanaan proses pembelajaran dari tiap siklus. Ketika melakukan observasi di dalam kelas, digunakan catatan (diary) dan lembar observasi untuk mencatat situasi selama pelaksanaan proses pembelajaran yang dalam hal ini pemanfaatan fonetik artikulatoris.

Kegiatan akhir pada pelaksanaan tindakan kelas adalah refleksi. Selama pelaksanaan proses pengajaran pelafalan pada tiap siklus, dapat dilihat bahwa kegiatan pembelajaran dan pengajaran bejalan dengan baik seperti yang direncanakan. Hasilnya cukup memuaskan karena terdapat peningkatan persentase nilai yang diperoleh siswa pada tes pelafalan awal (pretes) dan tes pelafalan akhir.

\section{HASIL TES AKHIR PELAFALAN}

Hasil yang diperoleh pada siklus I mengalami peningkatan dibandingkan hasil yang diperoleh dalam pelaksanaan pretes, begitu juga hasil yang diperoleh pada siklus II mengalami peningkatan dibandingkan pada siklus I. Hal ini membuktikan bahwa pemanfaatan fonetik artikulatoris melalui metode pengajaran intensif dapat membantu siswa meningkatkan kemampuan pelafalan mereka dalam berkomunikasi menggunakan bahasa Sasak.
Berikut ini pembahasan peningkatan kemampuan berbicara siswa pada siklus I dan II.

\section{Hasil Siklus I}

Hasil analisis menunjukkan nilai siswa yang diperoleh dalam kemampuan pelafalan mengalami peningkatan. Untuk lebih jelasnya, persentase nilai rata-rata dapat dilihat pada tabel berikut ini.

Persentase Nilai Tes Akhir (Posttest) Pelafalan Siklus I

\begin{tabular}{|c|c|c|c|}
\hline NO & SISWA & $\begin{array}{l}\text { NILAI } \\
\text { TOTAL }\end{array}$ & KATEGORI \\
\hline 1 & Siswa 1 & $56 \%$ & Kurang \\
\hline 2 & Siswa 2 & $60 \%$ & Cukup \\
\hline 3 & Siswa 3 & $64 \%$ & Cukup \\
\hline 4 & Siswa 4 & $59 \%$ & Kurang \\
\hline 5 & Siswa 5 & $69 \%$ & Cukup \\
\hline 6 & Siswa 6 & $80 \%$ & Baik \\
\hline 7 & Siswa 7 & $77 \%$ & Baik \\
\hline 8 & Siswa 8 & $84 \%$ & Baik \\
\hline & $\begin{array}{l}\text { Nilai } \\
\text { Siswa = }\end{array}$ & $\begin{array}{l}\text { Rata-Rata } \\
62 \%\end{array}$ & Cukup \\
\hline
\end{tabular}

Berdasarkan table hasil tes akhir siklus I menunjukkan bahwa nilai rata-rata yang diperoleh siswa adalah 68,62 \% dan termasuk dalam kategori cukup. Dari data tersebut dapat dilihat bahwa peningkatan kemampuan pelafalan yang didapatkan oleh anak down syndrome ringan sebesar $14,22 \%$ (persentase nilai rata-rata pada pretest sebesar $54,4 \%$ ).

\section{1) Tes Akhir Bunyi Vokal Siklus I}

Hasil tes akhir (posttest) siklus I pada bunyi vokal dalam penelitian ini menunjukkan bahwa para siswa yang sebelumnya sebagian besar telah mampu melafalkan bunyi vokal, meskipun ada beberapa siswa yang masih belum bisa melafalkan dengan benar, menunjukkan peningkatan dalam melafalkan bunyi vokal dalam berbicara bahasa Sasak. Hal ini dapat dilihat bahwa peningkatan kategori nilai yang diperoleh 
dari tes awal sampai tes akhir pada siklus I yaitu dari kategori baik berubah menjadi sangat baik.

Terdapat masing-masing $12 \%$ atau 1 dari 8 orang siswa masing-masing masih salah dalam melafalkan vokal $e$ yang seharusnya dilafalkan [ ə ] tetapi dilafalkan dengan bunyi [ e ] seperti dalam kata apel yang lafalnya[ apəl ] dilafalkan dengan [ apey ] dan vokal $o$ yang seharusnya dilafalkan dengan [ o ] tetapi dilafalkan dengan bunyi [ $\mathrm{O}$ ] seperti dalam kata lalo yang lafalnya [ lalo ] dilafalkan dengan [ yayO ]. Kesulitan dalam membedakan bunyi agak rendah [O] dengan bunyi yang agak tinggi [ o ] karena mereka mengalami kesulitan dalam memosisikan lidah yang sering menjadi penghambat untuk melafalkan bunyi vokal dengan tepat.

\section{2) Tes Akhir Bunyi Konsonan Siklus I}

Hasil tes akhir (posttest) siklus I pada bunyi konsonan dalam penelitian ini menunjukkan bahwa para siswa mengalami peningkatan kemampuan dalam melafalkan bunyi konsonan jika disbandingkan dengan hasil tes awal yang dilakukan sebelumnya. Tingkat pelafalan siswa mengalami peningkatan dari nilai rata-rata $44 \%$ (kurang) menjadi nilai rata-rata 67 $\%$ (cukup), sehingga peningkatan yang terjadi sebesar $23 \%$.

\section{Peningkatan kemampuan juga} ditunjukkan dengan berkurangnya jumlah siswa yang salah dalam melafalkan bunyi konsonan hambat yaitu hanya terdapat masing-masing 2 siswa yang masih salah melafalkan konsonan $d$ yang seharusnya dilafalkan dengan [ $\mathrm{d}$ ] seperti pada kata tedem yang lafalnya [ tedəm ] masih dilafalkan dengan [ tetəm ] dan bunyi [ $\mathrm{k}$ ] seperti pada kata kakak yang lafalnya [kaka?] masih dilafalkan dengan [ tcatca ]. Terdapat 4 siswa yang salah dalam melafalkan bunyi [ $\mathrm{g}$ ] seperti pada kata gule yang lafalnya [ gulə ] masih dilafalkan dengan [tulə] dan bunyi [ ? ]. Selain itu terdapat hanya 1 orang siswa yang masih salah melafalkan bunyi [ $\mathrm{n}$ ] seperti kata nani yang lafalnya [ nanI ] masih dilafalkan dengan [ ñañI ] dan terdapat 4 siswa yang salah dalam melafalkan bunyi [ $\eta$ ] seperti kata nginem yang lafalnya [ ๆInəm ] masih dilafalkan [ñIñəm] . Selain itu juga jumlah siswa yang salah dalam melafalkan bunyi $[\mathrm{s}],[\mathrm{j}],[1]$ dan bunyi [r] mulai berkurang.

\section{3) Tes Akhir Pelafalan Kata atau Frasa Siklus I}

Hasil tes awal penelitian ini menunjukkan bahwa hampir semua siswa anak down syndrome ringan di Pondok Harmoni Lombok Timur melakukan kesalahan dalam melafalkan kata dan frasa. Hasil tes akhir (posttest) siklus I dalam penelitian ini menunjukkan bahwa terjadi peningkatan pada kemampuan siswa dalam melafalkan kata dan frasa dalam melafalkan bahasa Sasak. Tingkat pelafalan siswa mengalami peningkatan dari nilai rata-rata 47,25 $\%$ (kurang) menjadi nilai rata-rata 62,75 \% (cukup), sehingga peningkatan yang terjadi sebesar $15,50 \%$.

\section{Hasil Siklus II}

Hasil analisis menunjukkan nilai siswa yang diperoleh dalam kemampuan pelafalan mengalami peningkatan. Untuk lebih jelasnya, persentase nilai rata-rata dapat dilihat pada tabel berikut ini.

Nilai Tes Akhir (Posttest) Pelafalan Siklus II

\begin{tabular}{llll}
\hline NO & SISWA & $\begin{array}{l}\text { NILAI } \\
\text { TOTAL }\end{array}$ & KATEGORI \\
\hline 1 & Siswa 1 & $67 \%$ & Cukup \\
\hline 2 & Siswa 2 & $66 \%$ & Cukup \\
\hline 3 & Siswa 3 & $71 \%$ & Baik \\
\hline 4 & Siswa 4 & $71 \%$ & Baik \\
\hline 5 & Siswa 5 & $76 \%$ & Baik \\
\hline 6 & Siswa 6 & $86 \%$ & Sangat Baik \\
\hline 7 & Siswa 7 & $82 \%$ & Baik \\
\hline 8 & Siswa 8 & $95 \%$ & Sangat Baik \\
\hline & Nilai & Rata-Rata & Baik \\
& Siswa = 76,75 \% & \\
\hline
\end{tabular}

Berdasarkan hasil tes akhir siklus II dalam pelafalan siswa menunjukkan bahwa nilai rata-rata yang diperoleh siswa adalah $76,75 \%$. 
Berdasarkan tabel Kriteria Acuan Penilaian Keterampilan Berbicara oleh Simon (2005:17), nilai rata-rata yang diperoleh siswa pada tes awal ini termasuk dalam kategori baik. Dari data tersebut dapat dilihat bahwa peningkatan kemampuan pelafalan yang didapatkan oleh anak down syndrome ringan sebesar 8,13\% jika dibandingkan dengan siklus I (persentase nilai rata-rata pada posttest siklus I sebesar 68,62 \%) dan sebesar 22,35 \% Jika dibandingkan dengan hasil pada tes awal (nilai rata-rata pretest sebesar $54,40 \%$.

\section{1) Hasil Tes Akhir Pelafalan Bunyi Vokal Siklus II}

Hasil tes akhir (posttest) siklus II pada bunyi vokal dalam penelitian ini menunjukkan bahwa para siswa yang sebelumnya sebagian besar telah mampu melafalkan bunyi vokal, meskipun ada beberapa siswa yang masih belum tepat melafalkan dengan benar, menunjukkan peningkatan dalam melafalkan bunyi vokal dalam berbicara bahasa Sasak. Nilai rata-rata yang diperoleh yaitu sebesar 97,50 \% yang berarti kemampuan anak down syndrome ringan dalam melafalkan bunyi vokal tetap termasuk dalam kategori sangat baik dengan peningkatan persentase nilai sebesar $11,5 \%$ (nilai rata-rata posttest siklus I $86 \%$ ).

Tes akhir siklus II dalam melafalkan bunyi vokal juga menunjukkan bahwa semua siswa telah mendapatkan nilai yang termasuk kategori sangat baik dalam melafalkan bunyi vokal dalam berbicara bahasa Sasak baik bunyi [ a ], [i ], [ u ], [ e ], [ ə ], [ $\varepsilon$ ], [ o ] dan bunyi [ O ] baik di awal, tengah ataupun akhir kata.

\section{2) Hasil Tes Akhir Pelafalan Bunyi Konsonan Siklus II}

Hasil tes akhir (posttest) siklus II pada bunyi konsonan dalam penelitian ini menunjukkan bahwa para siswa mengalami peningkatan kemampuan dalam melafalkan bunyi konsonan jika disbandingkan dengan hasil tes awal dan tes akhir siklus I yang dilakukan sebelumnya. Nilai rata-rata yang diperoleh sebesar $77 \%$ dan termasuk dalam kategori baik.
Tingkat pelafalan siswa mengalami peningkatan dari nilai rata-rata $67 \%$ (cukup) menjadi nilai rata-rata $77 \%$ (baik), sehingga peningkatan yang terjadi sebesar $10 \%$. Hasil tes akhir siklus II menunjukkan tidak ada siswa yang mendapatkan nilai sangat kurang atau kurang seperti sebelumnya.

Peningkatan juga ditunjukkan dengan berkurangnya jumlah siswa yang salah dalam melafalkan bunyi konsonan hambat yaitu hanya terdapat masing-masing 2 siswa yang masih salah melafalkan konsonan $k$ yang seharusnya dilafalkan [ $\mathrm{k}$ ] seperti pada kata kakak yang lafalnya [kaka?] masih dilafalkan dengan [ tcatca ], konsonan $g$ yang seharusnya dilafalkan [ g ] seperti pada kata gawe yang lafalnya [ gawe ] masih dilafalkan dengan [ hawe ] dan bunyi glotal [?] seperti pada kata amak yang lafalnya [ ama? ] masih dilafalkan dengan [ amah ]. Terdapat hanya 1 siswa yang masih salah melafalkan bunyi [ $\eta$ ] seperti pada kata gendang yang lafanya [ gəndā ] dilafalkan [ ondañ ]. Siswa juga sudah mampu melafalkan bunyi lateral dengan tepat dan hanya terdapat 2 siswa yang masih belum mampu melafalkan bunyi getar.

\section{3) Hasil Tes Akhir Pelafalan Kata atau Frasa Siklus II}

Hasil tes awal penelitian ini menunjukkan bahwa hampir semua siswa anak down syndrome ringan di Pondok Harmoni Lombok Timur melakukan kesalahan dalam melafalkan kata dan frasa. Hasil tes akhir (posttest) siklus I dalam penelitian ini menunjukkan bahwa terjadi peningkatan pada kemampuan siswa dalam melafalkan kata dan frasa dalam berbicara bahasa Sasak. kemampuan anak down syndrome ringan dalam melafalkan kata dan frasa bahasa Sasak mengalami peningkatan dari tes awal dan tindakan pada siklus I telah dilakukan sebelumnya meskipun tidak signifikan. Tingkat pelafalan siswa mengalami peningkatan dari nilai rata-rata $62,75 \%$ (cukup) menjadi nilai rata-rata $72 \%$ (baik), sehingga peningkatan yang terjadi sebesar $9,25 \%$. 
Grafik di bawah ini menggambarkan peningkatan nilai yang diperoleh siswa dari tes awal sampai tes akhir siklus I dan siklus II

Grafik Persentase Peningkatan Kemampuan Pelafalan Anak Down Syndrome Ringan

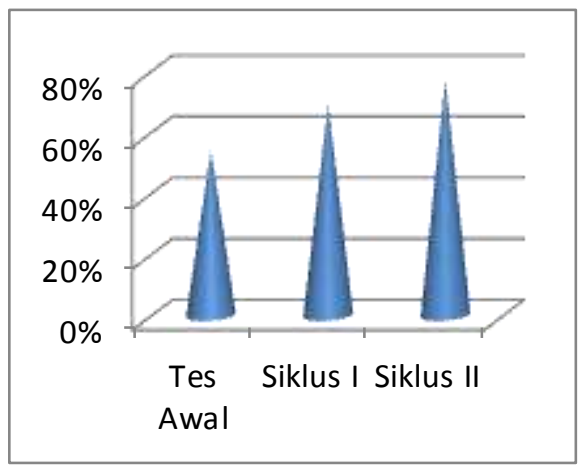

Grafik tersebut menunjukkan bahwa persentase nilai yang diperoleh siswa pada pretes mencapai nilai 54,40 \% dengan kategori kurang dan nilai tersebut jauh dari nilai standar. Pada Siklus I, persentase siswa mengalami peningkatan dan mencapai nilai $68,62 \%$ dengan kategori cukup. Hasil penelitian ini mencapai nilai yang baik pada siklus II dengan persentase nilai rerata yaitu $76,75 \%$ yang termasuk dalam kategori baik. Hasil tersebut menunjukkan bahwa penelitian ini sukses dan dihentikan pada siklus II. Selain peningkatan pada tiap-tiap tes secara umum, peningkatan yang lebih spesifik juga digambarkan pada grafik di bawah ini dengan menggambarkan peningkatan kemampuan pelafalan pada bunyi vokal, bunyi konsonan dan kata atau frasa.

\section{Grafik Peningkatan Kemampuan Pelafalan Bunyi Vokal, Konsonan dan Kata atau Frasa Anak Down Syndrome Ringan}

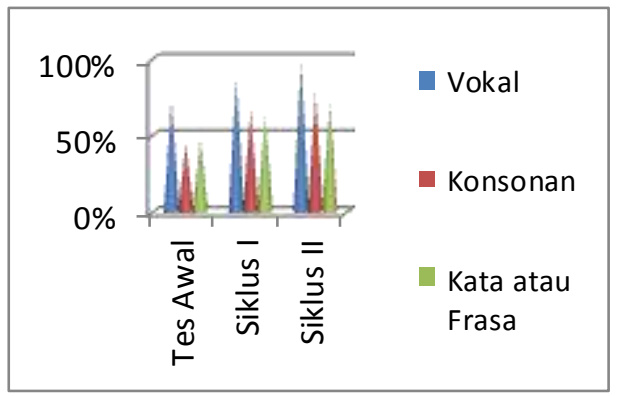

Hasil pada grafik menunjukkan bahwa persentase nilai rerata siswa mengalami peningkatan pada tiap-tiap aspek kemampuan berbicara pada tiap-tiap tes (pretes, postes I, dan postes II). Persentase tertinggi diperoleh pada aspek pelafalan bunyi vocal dengan persentase nilai yaitu mencapai $97.50 \%$ pada siklus II dan persentase terendah diperoleh pada aspek pelafalan kata atau frasa dengan persentase nilai mencapai $72 \%$ pada siklus II.

\section{SIMPULAN}

Berdasarkan hasil penelitian yang telah dilakukan, dapat disimpulkan bahwa kemampuan pelafalan siswa dalam berbicara bahasa Sasak meningkat setelah pemanfaatan fonetik artikulatoris diterapkan secara intensif dalam proses pengajaran. Hal tersebut dapat dibuktikan dengan meningkatnya hasil persentase nilai pada pretest ke siklus I dan dari siklus I ke siklus II. Peningkatan persentase nilai rerata siswa dalam pelafalan yang terjadi dari pretes dengan nilai $54,40 \%$, pada siklus I mengalami peningkatan menjadi $68,62 \%$, dan pada siklus II mengalami peningkatan menjadi $76,75 \%$.

\section{DAFTAR PUSTAKA}

Baihaqi, M Lutfi. 2011. "Kompetensi Fonologis Anak Penyandang Down Syndrome di SLB C Negeri 1 Yogyakarta". Jurnal Widyariset. Volume 14. Nomor 1.

Brown, H. Douglas. 2008. Prinsip - prinsip Pembelajaran dan Pengajaran Bahasa. (Cholis, Noor dan Yusi Avianto Pareanom, Pentj). Jakarta: Kedutaan Besar Amerika Serikat.

Hornby, A. S. 2005. Oxford Andvanced Learner's Dictionary of Current English. London: Oxford University Press.

Maidar Arsjad dan Mukti U.S. 2000. Pembinaan Kemampuan Berbicara Bahasa Indonesia. Jakarta: Erlangga 
Marsono. 2006. Fonetik. Yogyakarta: Gadjah Mada University Press.

Muslich, Mansur. 2012. Fonologi Bahasa Indonesia: Tinjauan Deskriptif Sistem Bunyi Bahasa Indonesia. Jakarta: Bumi Aksara

Santrock, John W. (2011). Perkembangan Anak Edisi 7 Jilid 2. (Terjemahan: Sarah Genis B) Jakarta: Erlangga.

Simon, Quinn. 2005. Debating Australia: Guidelines for Debaters (Australian Parliamentary System). Queensland: Debating Federation Author in Brisbane.

Singh, Sadanand dan Kala S. Singh. 1976. Phonetics: Principles and Practices. Baltimore: University Park Press.

Sulastowo, Mohammad. 2009. Pengantar Psikopedagogik Anak Berkelainan, Jakarta: Sinar Grafika Offset.

Suparwa, I Nyoman. 2008. "Persoalan Ortografi Untuk Bunyi Hambat-Glotal Dalam Bahasa Melayu Loloan Bali”. Jurnal Linguistika. Volume 15. Nomor 29.

Tarigan, Henry Guntur. 1998. Berbicara Sebagai Suatu Keterampilan Berbahasa. Bandung: PT. Angkasa Cipta. 